\title{
Agronomic performance of improved pearl millet cultivars in southern Chad
}

\author{
Gapili NAOURA $^{1^{*}}$, Nerbéwendé SAWADOGO ${ }^{2}$, Nadjiam DJIRABAYE ${ }^{1}$ and \\ Mahamat Alhabib HASSANE ${ }^{1 ; 2}$ \\ ${ }^{1}$ Institut Tchadien de Recherche Agronomique pour le Développement (ITRAD), B.P. 5400, N'Djaména, Tchad. \\ ${ }^{2}$ Université Joseph KI-ZERBO 03 BP 7021, Ouagadougou, 03, Burkina Faso. \\ *Corresponding author, E-mail: gapilinaoura@gmail.com; ITRAD, BP 23. N'Djamena, Chad, \\ Phone number: +23566574515
}

\begin{tabular}{lll}
\hline Received: 08-10-2020 & Accepted: 24-12-2020 & Published: 31-12-2020 \\
\hline
\end{tabular}

\begin{abstract}
Pearl millet [Pennisetum glaucum (L.) R. Br.] is a vital staple food crop for poor people in dry-land areas. It plays an important role on human consumption in South of Chad where farmers always used landraces with a little adoption of improved cultivars. Evaluation of agronomic performance of inbred cultivars at research station is important to identify the high performance genotype to be released as new cultivars in farmer area. So, five improved varieties associated with a well-known variety from research were evaluated for ten agronomical traits. Experiment was carried out during rainy season of 2019 at the research station of Bébédjia, South of Chad. The results of the analysis of variance of assessed traits showed high significant differences $(\mathrm{p}<0.001)$ for spike girth and slight significant difference $(\mathrm{p}<0.05)$ for days to flowering, thousand seeds weight and productive tillers per plant. An important positive and significant correlations were also noted between day to flowering and number of grains per plot $(\mathrm{r}=0.7 ; \mathrm{p}<0.01)$, seed weight per plot $(0.684 ; \mathrm{p}<0.01)$ and potential grain yield $(\mathrm{r}=0.684$; $\mathrm{p}<0.01)$. Moreover, three cultivars with an important potential grains yield namely ICMV167006 (4.99 t.ha $\left.{ }^{-1}\right)$, ICMV 167005 (4.68 t.ha ${ }^{-1}$ ) and ICMV177111 (3.98 t.ha $\left.{ }^{-1}\right)$ were identified. Otherwise, for the days to flowering, the cultivars ICMV167006 (73.67 days), ICMV 167005 (75.33 days) are earlier than ICMV 177111 (78.67 days). These cultivars could be proposed to be released in farmer area as novel cultivars.
\end{abstract}

(C) 2020 International Formulae Group. All rights reserved.

Keywords: Pearl millet, agromorphological characterization, cultivars, southern Chad.

\section{INTRODUCTION}

Pearl millet $(2 \mathrm{n}=2 \mathrm{x}=14)$ belongs to a highly heterozygous group that contains both wild and cultivated forms (Hancock, 1992). It is one of the most important staple cereals for subsistence farmers living in semiarid tropics of Africa and Asia., due to its high tolerance to drought, high temperatures, saline and marginal soils, and high capacity to buffer variable environmental conditions (Haussmann et al., 2012; 2016; Das, 2017). Approximately, 500 million people depend on pearl millet and it is currently grown on 28 million hectares throughout the world (Siddaiah et al., 2017). It is cultivated in diverse environments with harsh climate, frequent drought events and poor soil fertility where other cereal crops generally fail (Kumari 
et al., 2016; Sangwan et al., 2019). Pearl millet production is also hampered by several biotic constraints such the Millet Head Miner (Heliocheilus albipunctella De Joannis) and Downy mildew disease caused by Sclerospora graminicola (Sacc) Schroët (Halilou et al., 2017 ; Zoclanclounon et al., 2018; Kadri et al., 2019 ; Oumarou et al., 2020).

In Chad, pearl millet is the second important cereals after sorghum, grown in 1.23 million hectares which represent about $37 \%$ of total area planted under cereals. On 2018, the total production is 774,498 tones grains per year and occupies $27 \%$ of total cereals production of the country (DSA, 2018). Pearl millet grains are used for human consumption and for animal feed. It has higher protein, fat and balanced amino acid for human nutrition than that of wheat, maize or polished rice (Sawaya et al., 1984; Khairwal et al., 1999). According to Izge et al. (2007), it is a nutritious crop, producing almost all the required nutrients needed by humans. Filardi et al. (2005) reported that pearl millet produces higher protein levels than maize and have approximately $85 \%$ of energy content of maize.

The average productivity of pearl millet in Chad for the ten last years has been 525.44 kg.ha ${ }^{-1}$ for a maximum productivity of 636.51 kg.ha ${ }^{-1}$ (DSA, 2018). Several reasons are related to this fall of production in particular the exclusive use of landraces, by the producers. Even today, West and Central Africa farmers growing this cereal predominantly use pearl millet landraces (Busso et al., 2000; Dingkuhn et al., 2006). Improved varieties were released in farmer area by research during long time, however very little were adopted by them. Improving production of pearl millet while maintaining its production stability is crucial for food security for poor African smallholder farmers cropping under rain-fed farming systems (Pucher et al., 2015). According to Acquaah (2012), yield is the ultimate goal of plant breeding programs.
Assessment of news genetic material developed by breeding program is essential to identify a genotype to be released as cultivar to producers (Ceccarelli, 2009). The first stage to evaluate the news genotypes for identify superior genotypes is to study their agronomic performance at the research station, associate with a local existing variety more appreciated by farmers in this locality. Therefore, the current study aimed (i) to evaluate of level of agromorphological variability, (ii) to determine the agronomic performance and potential yield of assessed plant material and (iii) to select the best pearl millet cultivars as potential new cultivars to be release in southern Chad.

\section{MATERIALS ET METHODS \\ Plant material}

The experiment material included five pearl miller cultivars provided by International Crops Research Institute for the Semi-Arid Tropics (ICRISAT) in Niger and S 42, one superior cultivar well-known and more cultivated in environment of test of Bébédjia and considered as control in this test (Table 1).

\section{Experiment design and cultural practices}

The experiment was conducted under field conditions, at the experimental station of Bébédjia $\left(9^{\circ} 55^{\prime} \mathrm{N}\right.$ and $\left.15^{\circ} 8^{\prime} \mathrm{E}\right)$, at National Agricultural Research Institute of Chad (Institut tchadien de Recherche Agronomique pour le Développement, ITRAD), located in Logone Oriental region. It was set in a randomized block design with five replications and six treatments. Plot consisted of five rows of 5-m length, spaced 0.8-m apart.

Seeds were hand sowed $80 \mathrm{~cm}$ apart in the furrows, covered with soil using hoes and the soil compressed over the seed by walking several times over the seed rows. Sowing was realized on July 22, 2019 and fertilizer (NPK 10-10-10) was applied the same date at the rate of $100 \mathrm{~kg} \cdot \mathrm{ha}^{-1}$. At growth stage (August 08, 2019), plants were thinned to one plant per hole 
after weeds were removed by rotary hoe. Three weeks after the first management of weed control (August, 28 2019) the second removing weeds was done.

\section{Data collection}

Data are collected over all plant development stages. At the reproductive stage, flowing time was estimated as the number of days between sowing and full stigma emergence on main spike of $50 \%$ of plant on plot. The percentage of downy mildew-infested plants was recorded to determine the susceptibility of cultivars assessed. Total tillers per plot were determined by accounting the number of tillers in plot and after physiological maturity, the productive tillers per plant were determined counting the number of tillers for each. Before harvesting the plant height and spike girth were measured on 10 randomly selected plants on plot. After harvested and drying, the spikes of three central rows were gathered and seed weight per plot was measured using accuracy balance. The seed weight per plot was used to estimate the potential grain yield.

\section{Data analysis}

Data were subjected to the descriptive statistics (mean, standard deviation, coefficient of variation) and analysis of variance (ANOVA) using XLSTAT 2016 edition software. In addition, principal component analysis (PCA) was conducted after standardization to mean of zero and variance of one. The Pearson's correlation coefficients between each pairs of traits were performed. The heritability $\left(h^{2}\right)$ was categorized as suggested by Johnson et al. (1955) using GenStat $12^{\text {th }}$ edition software. In addition, means separation test of Newman-Keuls at the $5 \%$ threshold was performed to determine the significance of the means differences between ICRISAT pearl millet cultivars for the discriminating traits and to compare them to the tester.).

Table 1: pearl millet cultivars used as plant material.

\begin{tabular}{lcc}
\hline Cultivar code & Cultivar name & Origin \\
\hline V1 & CHAKTI & ICRISAT-Niger \\
V2 & ICMV 16001 & ICRISAT-Niger \\
V3 & ICMV 167005 & ICRISAT-Niger \\
V4 & ICMV 167006 & ICRISAT-Niger \\
V5 & ICMV 177 111 & ICRISAT-Niger \\
V6 & S 42 (Tester) & Bébédjia (Chad) \\
\hline
\end{tabular}




\section{RESULTS}

\section{Weather condition}

During the growing period of pearl millet, accounting between July and end of October, average of monthly relative humidity ranged from 85.16 (July) to $80 \%$ (October) and decreased rapidly to $67.47 \%$ in November (Figure 1). There was similarity between the average monthly and noon monthly relative humidity. At that time, the monthly morning relative humidity varied from 92.77 (July) to $93.68 \%$ (October) and decreased in November to $86.1 \%$. However monthly noon relative humidity varied from 71.68 (July) to $66.52 \%$ (October) and decreased in drastic manner to $43.2 \%$ in November. During the dry season from November to March relative humidity was down

The growing season during this study was characterized by monthly minimal air temperature, which ranged from 28.09 (April) to $23.87{ }^{\circ} \mathrm{C}$ (October) and the maximal air temperature which varied from 41.61 (April) to $34.54 \%$ (October). During the growing stage of the trial, from sowing (July) to harvesting (October), minimal air temperature ranged from 23.87 to $23.64{ }^{\circ} \mathrm{C}$ and maximal air temperature varied from 34.54 to $33.89^{\circ} \mathrm{C}$. The rainfall in growing season was $1180.6 \mathrm{~mm}$, started in April with $24.4 \mathrm{~mm}$ and ended in October with $107.2 \mathrm{~mm}$. August was the high wet month with $410.9 \mathrm{~mm}$ following by July with $243.6 \mathrm{~mm}$. During the wet period of August minimal and maximal air temperatures were the most down for the growing season, respectively 23.55 and $32.39{ }^{\circ} \mathrm{C}$ (Figure 2).

\section{Variation of assessed traits}

The results of analysis of variance of assessed traits (Table 2) showed high significant differences $(\mathrm{p}<0.001)$ only for spike girth and slight significant difference $(\mathrm{p}<0.05)$ for days to flowering, thousand seeds weight and productive tillers per plant. For the rest of traits, the difference among cultivars was nonsignificant $(p>0.05)$. Coefficient of variation
(CV) varied from $8.57 \%$ for days to flowering to $38.11 \%$ for productive tillers per plant. It was higher $(\mathrm{CV}>33 \%)$ for traits related to yield, especially for productive tillers per plant (38.11\%), seeds weight per plot $(33.95 \%)$ and potential grain yield $(33.95 \%)$. So the yield and yield component were more variables. For vegetative tillers per plot $(17.68 \%)$, plant height $(15.87 \%)$ and thousand grains weight (12.96\%), the CV were slight variables and for the days to flowering $(8.57 \%)$, variability was less variables.

Potential grain yield varied from 2.16 to 4.99 t.ha $^{-1}$, with an average of 3.57 t.ha ${ }^{-1}$. The flowering time ranged from 62 à 78.67 days, with an average of 73.17 days showing that, the assessed cultivars were early flowering varieties. The plant height averaged 197.9 $\mathrm{m} / \mathrm{plant}$ and ranged from 169.67 to 253.33 $\mathrm{m} /$ plant. Number of grains per unit area ranged from 17067 to 51862 grains per plot with an average of 33702 grains per plot. Seeds weight ranged from 173 to $399.33 \mathrm{~g} / \mathrm{plot}$ with a mean of $285.5 \mathrm{~g} /$ plot. The mean of spike girth was $8.8 \mathrm{~cm}$; the lowest was 6.93 and however a maximum spike girth was $11.8 \mathrm{~g}$. The vegetative tillers ranged from 76.67 to 123 per plot with an average of 94.9 and productive tillers ranged from 6.67 to 20.07 per plant with an average of 12.29 per plant. Downy mildew susceptibility ranged from 6 to $11.33 \%$ among cultivars with an average of $8.72 \%$.

\section{Relationship between traits}

Significant correlations between different quantitative traits assessed were revealed by Pearson correlation coefficient (Table 3). Spike girth was positively correlated only with thousand seed weight $(r=0.911$; $\mathrm{p}<0.001$ ) but negatively correlated with each of the rest of the traits. Thus, thousand seed weight was negatively correlated with seed weight per plot $(\mathrm{r}=-0.766 ; \mathrm{p}<0.01)$, potential grain yield $(r=-0.766 ; \mathrm{p}<0.01)$, plant height $(\mathrm{r}$ $=-0.785 ; \mathrm{p}<0.01)$, productive tiller per plant $(\mathrm{r}$ $=-0.746 ; \mathrm{p}<0.01)$, vegetative tiller per plot $(\mathrm{r}$ 
$=-0.893 ; \mathrm{p}<0.001)$ and number of days to flowering $(\mathrm{r}=-0.608 ; \mathrm{p}<0.01)$. In addition, day to flowering was positively correlated with number of grains per plot $(r=0.7 ; p<0.01)$, seed weight per plot $(0.684 ; \mathrm{p}<0.01)$ and potential grain yield $(\mathrm{r}=0.684 ; \mathrm{p}<0.01)$. Vegetative tiller per plot positively contributed to productive tiller per plant $(\mathrm{r}=0.882$; $\mathrm{p}<0.001)$. Plant height increase productive tillers per plant $(\mathrm{r}=0.879 ; \mathrm{p}<0.001)$ and vegetative tillers per plot $(r=0.882 ; p<0.001)$.

\section{Analysis of association between traits}

Principal component analysis (PCA) reduces the dimensions of multivariate data by removing inter-correlations among the traits being studied, thereby enabling multidimensional relationships to be plotted on two or three principal axes. The PCA based on eight traits (excluding yield) revealed that the first three principal components provided a reasonable summary of data and explained $93.727 \%$ of variance. The three PC explained $53.148 \%, 23.356 \%$ and $17.223 \%$ of the phenotypic variation, respectively for $\mathrm{PC} 1$, PC2 and PC3 (Table 4). Thousand seeds weight and spike girth length had relatively large positive influence on the first component. Conversely, number of vegetative tillers, number of grains per plot, seeds weight per plot, potential grain yield, and plant height had negative influence. The second component separated number of days to flowering, number of grains per plot, seed weight per plot and potential grains yield (yield and components) to plant height and number of productive tiller. The third PC axis was negatively influenced by flowering time, vegetative tillers and plant height.

\section{Performance analysis for assessed cultivars}

Average performance analysis of assessed cultivars for yield and yield component showed high difference among cultivars (Table 5). Variance component analysis indicated significant main effects of accessions for number of days to flowering $(\mathrm{p}=0.039)$, thousand seeds weight $(\mathrm{p}=0.011)$, number of productive tillers $(\mathrm{p}<0.016)$ and spike girth $(\mathrm{p}=0.0001)$. For seeds weight per plot, potential grains yield and plant height there was non-significant difference among cultivars.

The mean of flowering time ranged from 62 to 78.67 days. CHAKTI had an earlier flowering time (62 days) and the rest of the cultivars had more than 70 days for flowering time. ICMV 16001 (V2) had a heavier thousand seeds weight (10.43 g) followed by CHAKTI (9.83 g) and the cultivar ICMV 167 006 showed the smaller thousand seeds weight $(7.5 \mathrm{~g})$. The average plant height was highest for tester S42 $(253.33 \mathrm{~cm})$, followed by ICMV $167006(210.33 \mathrm{~cm})$ and ICMV 167005 (201 $\mathrm{cm})$. The tester $\mathrm{S} 42$ produced more productive tillers plant $(\approx 20)$ than the new cultivars assessed.

Regarding the seed weight per plot, the ICMV 167006 produced higher seed weight per plot (399.33 g), followed by ICMV 167005 (374.67 g) and ICMV 177111 (318.67 g). The tester S42, used to compare the new cultivars produced only $272 \mathrm{~g}$ seeds per plot. Considering the number of grains per plot, cultivar ICMV 167006 produced higher number of grains per unit of area (51862 grains), followed by ICMV 167005 (43395 grains) and S 42 (36620 grains). The average potential grain yield was higher for ICMV 167 006 (V4), which produced 4.99 t.ha $^{-1}$, followed by ICMV $167005\left(\mathrm{~V} 3=4.68 \mathrm{t}^{\mathrm{h}} \mathrm{ha}^{-1}\right)$ and ICMV $177111\left(\right.$ V5 = 3.98 t.ha $\left.^{-1}\right)$. These three cultivars were identified more superior than the existing variety more produced by the farmers and used as a tester. 
G. NAOURA et al. / Int. J. Biol. Chem. Sci. 14(9): 2980-2991, 2020

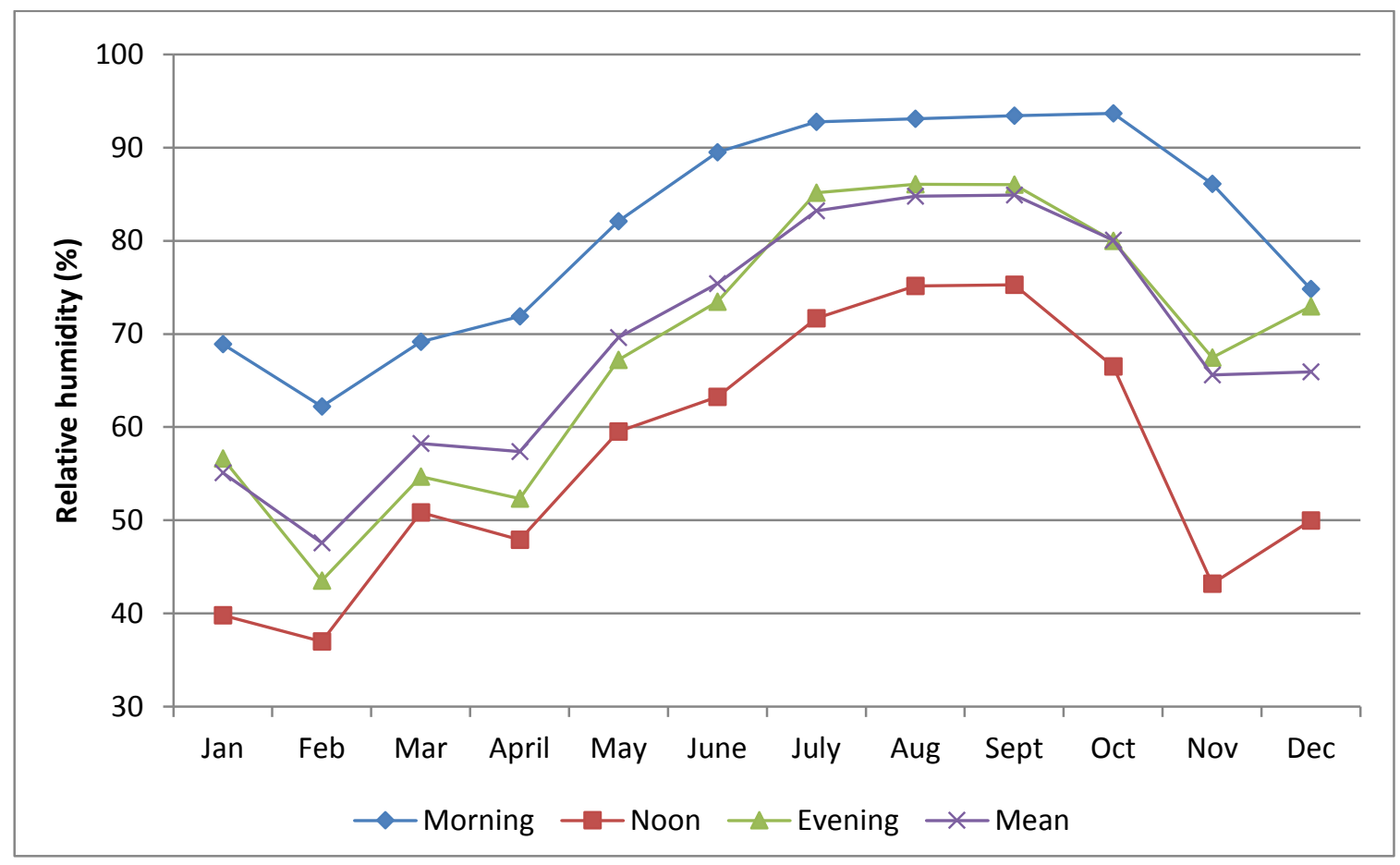

Figure 1: Air humidity relative during year of experiment.

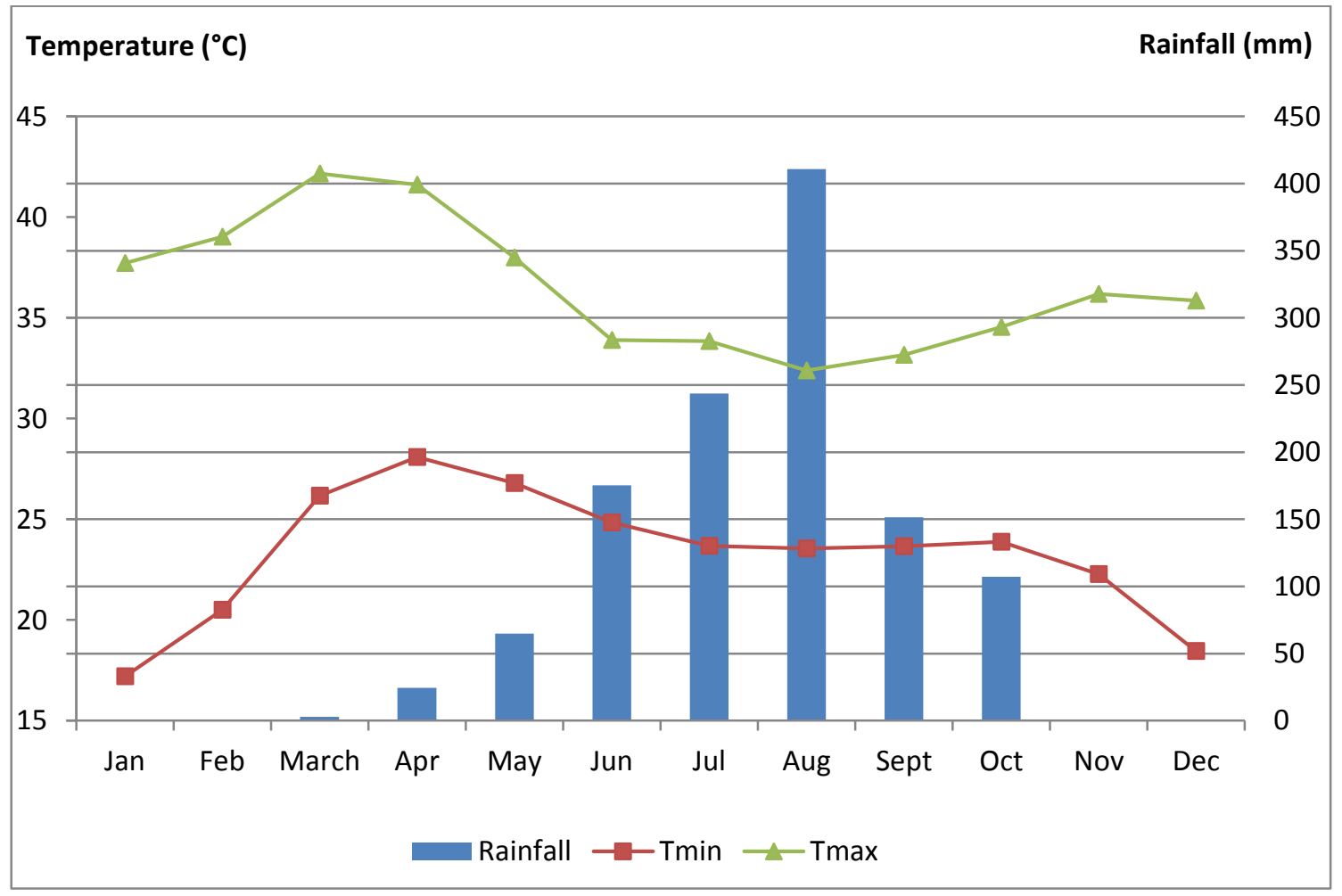

Figure 2: Air temperature and rainfall condition during year of experiment. 
Table 1: Results of analysis of variance and broad sense heritability of assessed traits.

\begin{tabular}{|c|c|c|c|c|c|}
\hline Traits & Minimum & Maximum & Mean & CV $(\%)$ & $\mathrm{H}^{2}(\%)$ \\
\hline Days to flowering (day) & 62 & 78.67 & $73.17 \pm 6.27$ & $8.57^{*}$ & 70.48 \\
\hline $\begin{array}{l}\text { Downy mildew-infested plants } \\
(\%)\end{array}$ & 6 & 11.33 & $8.72 \pm 1.95$ & $22.34^{\text {ns }}$ & 27.83 \\
\hline Thousand grains weight (g) & 7.5 & 10.43 & $8.89 \pm 1.15$ & $12.96^{*}$ & 79.52 \\
\hline Seeds weight per plot (g) & 173 & 399.33 & $285.5 \pm 96.9$ & $33.95^{\text {ns }}$ & 37.07 \\
\hline Number of grains per plot & 17067 & 51862 & $33702 \pm 14007$ & $41.56^{\mathrm{ns}}$ & 37.07 \\
\hline Potential grain yield (t.ha ${ }^{-1}$ ) & 2.16 & 4.99 & $3.57 \pm 1.21$ & $33.95^{\mathrm{ns}}$ & 37.07 \\
\hline Plant height (cm) & 169.67 & 253.33 & $197.9 \pm 31.4$ & $15.87^{\mathrm{ns}}$ & 60.03 \\
\hline Vegetative tillers per plot & 76.67 & 123 & $94.9 \pm 16.8$ & $17.68^{\mathrm{ns}}$ & 65.23 \\
\hline Productive tillers per plant & 6.67 & 20.07 & $12.29 \pm 4.68$ & $38.11^{*}$ & 77.46 \\
\hline Spike girth $(\mathrm{cm})$ & 6.93 & 11.8 & $8.8 \pm 1.76$ & $20.00^{* * * *}$ & 98.18 \\
\hline
\end{tabular}

Significant: ${ }^{*} \mathrm{p}<0.05 ; * * * \mathrm{p}<0.001 ; \mathrm{CV}$ : coefficient of variation; $\mathrm{H}^{2}$ : heritability

Table 2: Pearson's correlation coefficient among agronomical assessed traits.

\begin{tabular}{|c|c|c|c|c|c|c|c|c|}
\hline Variables & DFL & VTL & TSW & NGU & SWP & PGY & PHT & PTL \\
\hline VTL & $0.611^{* *}$ & & & & & & & \\
\hline TSW & $-0.608^{* *}$ & $-0.893^{* * *}$ & & & & & & \\
\hline NGU & $0.700^{* *}$ & $0.621^{* *}$ & $-\mathbf{0 . 8 8 0} 0^{* * * *}$ & & & & & \\
\hline SWP & $0.684^{* *}$ & $0.461^{*}$ & $-0.766^{* *}$ & $0.978^{* * * *}$ & & & & \\
\hline PGY & $0.684^{* *}$ & $0.461^{*}$ & $-0.766^{* * *}$ & $0.978^{* * *}$ & $\mathbf{1}^{* * *}$ & & & \\
\hline PHT & $0.560^{*}$ & $0.916^{* * * *}$ & $-0.785^{* * *}$ & $0.480^{*}$ & 0.311 & 0.311 & & \\
\hline PTL & 0.222 & $0.882^{* * *}$ & $-0.746^{* *}$ & 0.352 & 0.172 & 0.172 & $0.879^{* * * *}$ & \\
\hline SPG & $-0.536^{* * *}$ & $-0.752^{* *}$ & $0.911^{* * *}$ & $-0.887^{* * *}$ & $-0.830^{* * * *}$ & $-0.830^{* * * *}$ & $-0.517^{*}$ & $-0.587^{*}$ \\
\hline
\end{tabular}


Table 3: Principal component (PC) matrix explaining loading of variables.

\begin{tabular}{lccc}
\hline Axis & PC1 & PC2 & PC3 \\
\hline Eigenvalue & 7.441 & 3.270 & 2.411 \\
\% of total variance & 53.148 & 23.356 & 17.223 \\
Cumulative variance (\%) & 53.148 & 76.504 & 93.727 \\
Days to flowering & -0.248 & $\mathbf{0 . 2 2 6}$ & $\mathbf{- 0 . 3 6 0}$ \\
Vegetative tiller & $\mathbf{- 0 . 2 9 7}$ & -0.197 & $\mathbf{- 0 . 2 7 5}$ \\
Thousand seeds weight & $\mathbf{0 . 3 5 9}$ & 0.081 & 0.038 \\
Number of grains per unit area & $\mathbf{- 0 . 3 3 8}$ & $\mathbf{0 . 2 9 4}$ & 0090 \\
Seed weight per plot & $\mathbf{- 0 . 3 1 7}$ & $\mathbf{0 . 2 5 6}$ & 0.094 \\
Potential grain yield & $\mathbf{- 0 . 3 1 7}$ & $\mathbf{0 . 2 5 6}$ & 0.094 \\
Plant height & $\mathbf{- 0 . 2 6 5}$ & $\mathbf{- 0 . 2 7 8}$ & $\mathbf{- 0 . 2 4 6}$ \\
Productive tiller & -0.229 & $\mathbf{- 0 . 4 0 6}$ & -0.149 \\
Spike girth & $\mathbf{0 . 3 3 0}$ & $\mathbf{- 0 . 0 2 3}$ & 0.011 \\
\hline
\end{tabular}

Table 4: Results of Neman Keuls average separation test of the traits of pearl millet cultivars assessed.

\begin{tabular}{|c|c|c|c|c|c|c|c|c|}
\hline & $\overline{\text { DFL }}$ & TSW & SWP & NGP & PGY & PHT & PTL & SPG \\
\hline ICMV 167006 & $73.67 \mathrm{ab}$ & $7.5 \mathrm{~b}$ & 399.33 a & 51863 & $4.99 \mathrm{a}$ & $210.33 \mathrm{a}$ & $14.27 \mathrm{ab}$ & $6.93 \mathrm{~d}$ \\
\hline ICMV 167005 & $78.67 \mathrm{a}$ & $8.7 \mathrm{ab}$ & 374.67 a & 43395 & $4.68 \mathrm{a}$ & $201 \mathrm{a}$ & $10.53 \mathrm{~b}$ & $8.47 \mathrm{c}$ \\
\hline S 42 & $78.67 \mathrm{a}$ & $7.73 \mathrm{~b}$ & $272 \mathrm{a}$ & 36621 & $3.4 \mathrm{a}$ & 253.33 a & 20.07 a & $7.8 \mathrm{c}$ \\
\hline ICMV 177111 & $75.33 \mathrm{ab}$ & $9.13 \mathrm{ab}$ & 318.67 a & 35909 & $3.98 \mathrm{a}$ & $169.67 \mathrm{a}$ & $9.13 \mathrm{~b}$ & $7.93 \mathrm{c}$ \\
\hline CHAKTI & $62 \mathrm{~b}$ & $9.83 \mathrm{ab}$ & $173 \mathrm{a}$ & 17358 & $2.16 \mathrm{a}$ & $177.33 \mathrm{a}$ & $13.07 \mathrm{ab}$ & $9.87 \mathrm{~b}$ \\
\hline ICMV 16001 & $70.67 \mathrm{ab}$ & $10.43 \mathrm{a}$ & $175.33 \mathrm{a}$ & 17066.6 & $2.19 \mathrm{a}$ & $176 \mathrm{a}$ & $6.67 \mathrm{~b}$ & $11.8 \mathrm{a}$ \\
\hline $\operatorname{Pr}>\mathrm{F}$ & 0.039 & 0.011 & 0.236 & 0.169 & 0.236 & 0.090 & 0.016 & 0.0001 \\
\hline Significant & Yes & Yes & No & No & No & No & Yes & Yes \\
\hline
\end{tabular}




\section{DISCUSSION}

Assessment of five new cultivars of pearl millet in southern Chad compared with an existing variety as control was carried out to identify superior genotype that can be released as a new cultivar to farmers for commercial production. The result of this study indicated that during the growing season of experiment, average relative humidity ranged from 85.16 (July) to $80 \%$ (October). Minimal air temperature varied from 23.87 to $23.64{ }^{\circ} \mathrm{C}$ and maximal air temperature ranged from 34.54 to $33.89^{\circ} \mathrm{C}$. The rainfall was $1180.6 \mathrm{~mm}$; started in April with $24.4 \mathrm{~m}$ and ended in October with $107.2 \mathrm{~mm}$. The cultivars were sowed July 22 , 2019 and during the growing period of cultivars weather was good with regular rain and nice minimal and maximal air temperature. These indicated that experiment was realized in the optimum weather conditions for the development of pear millet.

Large variations between cultivars were observed for some traits assessed through analysis of variance. For days to flowering, thousand seeds weight, productive tillers and spike girth highly and significant variation among cultivars were observed. For number of grains per plot, seeds weight per plot, potential grain yield, plant height and vegetative tillers, although the difference between cultivar was not significant, these traits showed high coefficients of variation (>33\%) expressed dispersal of cultivars values of these regarding mean value. According to Acquaah (2012), coefficient of variation is a measure of the relative variability of given populations. Number of productive tillers showed highly variation (CV: $38.11 \%)$. Kumari et al. (2016) and Gapili et al. (2019) reported similar results. They obtained a CV of $38 \%$ and $43.3 \%$ respectively for the same trait. Previous study realized on pearl millet landrace from South of Chad found that all assessed traits except total tiller per plant revealed high significant difference between twelve landraces (Gapili et al., 2019). Govindaraj et al. (2010) found highly significant differences among accessions from India for almost assessed traits except for number of productive tillers and days to maturity. Evaluation of downy mildew susceptibility showed that an average of $8.72 \%$ was attacked. Pucher et al. (2015) on West and Central African pearl millet accessions registered a higher value of $17.49 \%$. Study realized on Indian pearl millet found that out of 221 accessions, 107 accessions were free from downy mildew disease significantly (Kumari et al., 2016). Pearl millet cultivar grew even less than $254 \mathrm{~cm}$ with a mean value of $197.9 \mathrm{~cm}$ with the taller plants from tester S42. All assessed cultivars were characterized by early and medium flowering time (62 to 78.67 days), good productive tillers capacity (from 6.67 to 20 tillers).

Study noted marked relationships between the various traits measured. Flowering time is positively correlated with yield and yield component. According to Gapili et al. (2019) number of days to flowering is highly positively correlated with weight of main spike and grain weight per main spike (yield components). Contrariwise, study realized by Bidinger et al. (1987) found a strong negative correlation between flowering time and grain yield when pearl millet receives terminal drought stress. According to Pucher et al. (2015), the correlation between flowering time and grain yield varied across test environments. Seeds weight per plot and number of seed per plot enhanced significantly the potential grain yield. According to Araus et al. (2009), the two main yield components are the number of grains per unit area and the averaged individual grain weight.

PCA reduces the number of variables to be used for prediction and description (Acquaah, 2012). These procedures are used to reduce the number of variables and to detect structure in the relationships between these variables (Karsai et al., 2010). The current study allowed seeing strong association among flowering time, vegetative tiller and plant height on the one hand. On the other hand, high relation was observed among number of vegetative tiller, number of grains per plot, seed weight per plot, potential grain yield, and plant height.

In this study the existing variety used as a control produced taller plant $(253.33 \mathrm{~cm})$ than the new cultivars. According to Ceccarelli 
et al. (2000) and Annicchiarico et al. (2005), reduced plant height has been one of the major causes of lack of adoption of modern varieties in a number of crops grown by farmers in developing countries as animal feed and where the way in which total biomass is portioned is irrelevant. In Chad, farmers used the pearl millet straw to build roofs and for animal feed. Regarding thousand grains weight, cultivar ICMV 16001 showed highest value (10.43 g), followed by CHAKTI ( $9.83 \mathrm{~g}$ ) and ICMV 177 $111(9.13 \mathrm{~g})$. The smaller thousand grains weight was for ICMV 167006 which had 7.5 g. study realized on pearl millet accessions from West and Central Africa found the thousand grains weight ranged from 4.5 to 13.5 $\mathrm{g}$ with an average of $8.7 \mathrm{~g}$ (Sattler et al., 2017). Cultivar ICMV 167006 produced higher seed weight per plot with higher number of seeds per plot (399.33 g and 518623 respectively), followed by ICMV 167005 (374.67 g and 43395) and ICMV 177111 (318.67 g and 35909). According to Araus et al. (2009) the number of grains per unit area and the averaged individual grain weight are the two main yield components, these three cultivars mentioned above with higher seed weight per plot and higher number of grains per plot were the higher potential grains yield. Then, cultivar ICMV 167006 produced the higher potential grains yield $\left(4.99\right.$ t.ha $\left.^{-1}\right)$, followed by ICMV 167005 (4.68 t.ha $\left.{ }^{-1}\right)$ and ICMV 177111 (3.98 t.ha $\left.{ }^{-1}\right)$.

In fact, the average productivity of pearl millet in Chad for the ten last years has been $525.44 \mathrm{~kg} \cdot \mathrm{ha}^{-1}$ for a maximum productivity of $636.51 \mathrm{~kg} \cdot \mathrm{ha}^{-1}$ (DSA, 2018). In other countries like India, average productivity of pearl millet was $930 \mathrm{~kg} \cdot \mathrm{ha}^{-1}$ (AICPMIP, 2017). Some studies in India showed that a hybrid variety of pearl millet produced $1270 \mathrm{~kg} \cdot \mathrm{ha}^{-1}$ (Gupta et al., 2015). Then these three cultivars with higher potential grains yield were more productive than average production of pearl millet in Chad. They could be released as new cultivars to farmers for commercial production. Once new and potential promising lines are identified by agricultural research, it is essential to commercialize and make their seeds available to farmers

\section{Conclusion}

The results of our study indicated that days to flowering, thousand seeds weight, productive tillers and spike girth showed significant difference among cultivars. Flowering time ranged from 62 to 78.67 showing that assessed cultivars had earlier flowering time. Pearson's coefficient of correlation showed high relation between day to flowering and grains potential yield and yield components. Among the news assessed pearl millet three cultivars ICMV 167006 (4.99 t.ha ${ }^{-1}$ ), ICMV 167005 (4.68 t.ha $\left.{ }^{-1}\right)$ and ICMV 177111 (3.98 t.ha ${ }^{-1}$ ) produced higher grains yield potential than the well-known cultivar (S42) which reached 3.4 t.ha $^{-1}$ grains yield potential. These cultivars could be assessed in farmer trial to associate producers in the definitely choice of the new cultivars to be released in farmer area.

\section{COMPETING INTERESTS}

The authors declare that they have no competing interests.

\section{AUTHORS' CONTRIBUTIONS}

GN, NS, and ND designed the research. GN and NS wrote the manuscript and performed the experiments. GN, NS and MAH, analyzed the data. All authors read and approved the final manuscript.

\section{ACKNOWLEDGEMENTS}

The authors would like to thank Dimlelngar Marc and Ganezoune Michel for field management and data collected.

\section{REFERENCES}

Acquaah G. 2012. Principal of Plant Geneticsand Breeding, second ed. WileyBlack Well, ISBM: 978-0-470-66476-6.

AICPMIP. 2017. Project Coordinator's Review. Available from: www.aicpmip.res.in/pcr2017.pdf

Annicchiarico P, Abdellaoui M, Kerkouli M, Zerargui H. 2005. Grain yield, straw yield and economic value of tall and semi-dwarf durum wheat cultivars in Algeria. Journal of Agricultural Science, 143: 57-64. 
Araus JL, Slafer GA, Reynolds MP, Royo C. 2009. Breeding for quantitative variables part: Breeding for yield potential. In Plant Breeding and Farmer Participation, Ceccarelli S, Guimaraes EP, Weltzien E (eds). Food Agriculture Organization of the United Nations: Rome.

Bidinger FR, Mahalakshmi V, Rao GDP. 1987. Assessment of drought resistance in pearl millet [Pennisetum americanum (L.) Leeke]. I. Factors affecting yields under stress. Aust. J. Agric. Res., 38: 37-48. DOI: 10.1071/AR9870037

Busso C, Devos KM, Ross G, Mortimoe M, Adams WM, Ambrose MJ, Alldrick S, Gale MD. 2000. Genetic diversity within and among landraces of pearl millet (Pennisetum glaucum) under farmer management in West Africa. Genet. Resour. Crop Evol., 47: 561-568. DOI: 10.1023/A:1008767220320

Ceccarelli S, Grando S, Tutwiler R, Baha J, Martini AM, Salahieh H, Goodchild A, Michael M. 2000. A methodological Study on Participatory Barley Breeding. I. Selection Phase. Euphytica, 111: 91-104. DOI: https://doi.org/10.1023/A:100371730386 9.

Ceccarelli, S. 2009. Main stages of a plant breeding programme, In Plant Breeding and Farmer Participation Ceccarelli S, Guimaraes EP, Weltzien E (eds). FAO: Rome, Italy; 63-74.

Das IK. 2017. Millet Diseases, Current Status and Their Management. In Millets and Sorghum: Biology and Genetic Improvement, Patil JV (ed.). John Wiley \& Sons, Ltd: New York, USA; 291-322.

Dingkuhn M, Singh BB, Clerget B, Chantereau J, Sultan B. 2006. Past, present, and future criteria to breed crops for water-limited environments in West Africa. Agric. Water Manage., 80: 241-261. DOI: 10.1016/j.agwat.2005.07.016

DSA (Direction Statistique Agricole). 2018. Ministère de la Production de l'Irrigation et des Equipement Agricole du Tchad. Rapport 2018.
Filardi RS, Junqueira OM, Casartelli EM, Laurentiz AC, Duarte KF, Assuena V. 2005. Pearl millet utilization on commercial laying hen diets formulated on a total or digestible amino acid basis. Revista Brasileira de Ciencia Avicola, 7(2):

56-64.

http://dx.doi.org/10.1590/S1516635X2005000200006.

Gapili N, Djinodji R, Mahamat AH, Serferbe S. 2019. Ethnobotanical and Agromorphological Assessment of Pearl Millet [Pennisetum glaucum (L.) R. Br.] Accession from South of Chad. International Journal of Agriculture, Environment and Bioresearch, 4 (06).

Govindaraj M, Shanmugasundaram P, Muthiah AR. 2010. Estimates of genetic parameters for yield and yield attributes in elite lines and popular cultivars of India's pearl millet. African Journal of Agricultural Research, 5(22): 3060-3064. http://www.academicjournals.org/AJAR

Gupta SK, Nepolean T, Sankar SM, Rathore A, Das RR, Rai KN, Hash CT. 2015. Patterns of molecular diversity in current and previously developed hybrid parents of pearl millet [Pennisetum glaucum (L.) R. Br.]. Am. J. Plant Sci., 6: 1697-1712. http://dx.doi.org/10.4236/ajps.2015.6111 69

Haussmann BIG, Rattunde HF, WeltzienRattunde E, Traore PSC, vom Brocke K, Parzies HK. 2012. Breeding strategies for adaptation of pearl millet and sorghum to climate variability and change in West Africa. J. Agron. Crop Sci., 198: 327-339. doi:10.1111/j.1439-037X.2012.00526.x

Hancock JF. 1992. Plant Evolution and Origin of Crop Species. Prentice-Hall Inc. A Simon \& Schuster Company, Englewood Cliffs: New Jersey.

Halilou H, Kadri A, Karimou I. 2017. Gestion intégrée du mildiou du mil en station au centre régional de recherche agronomique de Maradi (CERRA/Maradi) au Niger. Int. J. Biol. Chem. Sci., 11(6): 2704-2712. DOI:

https://dx.doi.org/10.4314/ijbcs.v11i6.12 
Izge, Kadams AM, Sajo AA. 2007. Agronomic Performance of Selected Cultivars of Pearl Millet (Pennisetum glaucum L.R.Br.) and their Hybrids in North-Eastern Nigeria. Journal of Agronomy, 6(2): 344-349. DOI: 10.3923/ja.2007.344.349

Johnson HW, Robinson HF, Comstock RE. 1955. Estimates of genetic and environmental variability in soybean. Agronomy J., 47(7): 314-318. https://doi.org/10.2134/agronj1955.0002 $1962004700070009 x$

Kadri A, Halilou H, Karimou I. 2019. Culture du mil [Pennisetum glaucum (L) R. Br] et ses contraintes à la production: une revue. Int. J. Biol. Chem. Sci., 13(1): 503-524. DOI: https://dx.doi.org/10.4314/ijbcs.v13i1.40

Karsai, I, Meszaros K, Lang L, Hayes PM, and Bedo Z. 2000. Multivariate analysis of traits determining adaptation in cultivated barley. Plant Breeding, 120(3): 21-222. DOI: $\quad$ https://doi.org/10.1046/j.14390523.2001.00599.x

Khairwal IS, Rai KN, Andrews DJ, Harinarayana G. 1999. Pearl Millet Breeding. Oxford and IBH: New Delhi, India.

Kumari J, Bag MK, Pandey S, Jha SK, Chauhan SS, Jha GK, Gautam NK, Dutta M. 2016. Assessment of phenotypic diversity in pearl millet [Pennisetum glaucum (L.) R. Br.] Germplasm of Indian origin and identification of trait-specific germplasm. Crop \& Pasture Science, 67(12) : 1223-1234. DOI: http://dx.doi.org/10.1071/CP16300

Oumarou MN, Ibrahim Baoua I, Abdoul Aziz Saidou AA, Amadou LL. 2020. Evaluation des génotypes de mil Pennisetum glaucum (L.) R. Br. pour la résistance ou la tolérance à la mineuse de l'épi de mil, Heliocheilus albipunctella
De Joannis au Niger. Int. J. Biol. Chem. Sci., 14(2): 501-512. DOI: https://dx.doi.org/10.4314/ijbcs.v14i2.16 Pucher A, Sy O, Angarawai II, Gondah J, Zangre R, Ouedraogo M, Sanogo MD, Boureima S, Hash CT, Haussmann BIG. $2015 . \quad$ Agro-morphological Characterization of West and Central African Pearl Millet Accessions. Crop Sci. 55: 737-748. DOI: 10.2135/cropsci2014.06.0450

Sangwan S, Yashveer S, Kumar K, Hemender, Sharma S, Redhu N. 2019. Multi Trait Analysis Reveals Substantial Diversity in Pearl Millet [Pennisetum glaucum (L.) R. Br.] Inbred Lines. Journal of Experimental Biology and Agricultural Sciences, 7(4): 358-375.

DOI: http://dx.doi.org/10.18006/2019.7(4).358. 375

Sattler FT, Sanogo MD, Kassari IA, Angarawai I, Gwadi I K, Dodo H, Haussmann BIG. 2017. Characterization of West and Central African accessions from a pearl millet reference collection for agromorphological traits and Striga resistance. Plant Genetic Resources, 16(3): 260-272. DOI: 10.1017/S1479262117000272

Sawaya WN, Khalil JK, Safi WJ (1984) Nutritional quality of pearl-millet flour and bread. Plant Foods for Human Nutrition, 34: 117-125. DOI: 10.1007/BF01094839

Zoclanclounon YAB, Kanfany G, Thiaw C, Fofana A, Mbaye N, Cisse N. 2018. Assessment of pearl millet genotypes for downy mildew resistance and agronomic performance under field conditions in senegal. Int. J. Agric. Biol., 20: 493-498. DOI: 10.17957/IJAB/15.0504. 